Agriculture, Agrobusiness and Biotechnology

Vol.60: e17161229, January-December 2017 http://dx.doi.org/10.1590/1678-4324-2017161229 ISSN 1678-4324 Online Edition

AN INTERNATIONAL JOURNAL

\title{
Economic Viability of Tomato Cultivation in Organic Farming System
}

\author{
José dos Santos Neto', Kátia Regina Freitas Schwan-Estrada², José Ozinaldo Alves de \\ Sena $^{2}$, Tiago Santos Telles ${ }^{1 *}$. \\ ${ }^{1}$ Instituto Agronômico do Paraná, Londrina, Paraná, Brasil; ${ }^{2}$ Universidade Estadual de Maringa, Departamento de \\ Agronomia, Maringá, Paraná, Brasil.
}

\begin{abstract}
The aim of the present study is to evaluate the economic viability of tomato cultivation in a system of organic farming, and to compare it with the conventional farming system. The fixed and variable costs of both cultivation systems were calculated, as well as the costs of disease control with the application of alternative products and pesticides. The revenues were computed using commercial production and the direct sales price. The total cost per area was higher in the conventional system, while the cost per plant was greater in the organic system, since it used a lower plant population density. In the conventional system, 2.33 times more was spent on plant management, due to the fact that the number of sprayings was greater than that carried out in organic farming. We further find that companion planting with other species such as coriander, in addition to helping with the management of the main crop, is important for economic sustainability as it is an extra source of income. Considering the specificities of the two systems, the profitability of organic cultivation, even accounting for its lower productivity, could exceed that of conventional cultivation.
\end{abstract}

Key words: sustainability, Solanum lycopersicum, Cymbopogon citratus, costs of production, production systems

\footnotetext{
*Author for correspondence: telles@iapar.br, tiagotelles@yahoo.com.br
} 


\section{INTRODUCTION}

Beginning in the 1970's, with the increase in reporting on environmental impacts such as deforestation, desertification, and contamination of the soil, water, and air by toxic residues related to conventional agricultural practices a growth in environmental awareness became evident across the planet. Consequently, greater interest arose in alternative production systems and methods like organic farming, which were considered to be more sustainable[ $\left.{ }^{1,2}\right]$.

Organic farming systems are founded on agro-ecological strategies that involve the use of local inputs, thus adding value to the product and providing a fairer supply chain $[3,4]$. Moreover, organic farming usually incorporates environmental conservation, social commitment of agriculture to farmers and consumers, and the quest for ecological sustainability into its systems of production.

The growth in organic farming and agroecology is a response to societal demands for safer, healthier production practices, or, in other words, production practices that assure the health of both man and his environment $\left[{ }^{5}\right]$. Given this scenario, some consumers prefer to acquire products with these (organic) characteristics, despite having to pay a price premium relative to foods produced via more conventional methods. This propensity to pay a premium for organic foods opens up an important niche in the market for such products $\left[{ }^{6}\right]$.

Few studies have been published on the economic viability of food production in a system of organic farming $\left[{ }^{7,8,9}\right]$. This information is crucial for those looking to adopt this system, especially with crops that require large investment, as is the case with tomatoes. Ultimately, can we say that the organic tomato production system is economically viable in comparison with the conventional system.

We hypothesize that organic tomato cultivation could be economically viable, and that it could be an option for diversification in agricultural concerns, especially family-run businesses.

The aim of the present study is to evaluate the economic viability of tomato plant cultivation in a system of organic farming, and to compare it with the conventional cultivation system, taking into account the technical specificities of each system.

\section{MATERIAL AND METHODS}

For the economic-viability analysis of tomato production, organic and conventional farming systems were analyzed. Both production systems were located in the metropolitan region of Maringá, in the state of Paraná, and both used the same tomato variety over the same time period.

\section{Organic farming system}

Cultivation was undertaken in the agro-ecological sector of the Iguatemi Experimental Farm at the State University of Maringá, which was certified for organic cultivation by the Brazilian inspection and certification agency known as ECOCERT (certificate no. 3159BR), between May 26 and October 25, 2011. The area possesses the following characteristics: altitude of $545 \mathrm{~m}$, latitude $23^{\circ} 25^{\prime} \mathrm{S}$, longitude $51^{\circ} 25^{\prime} \mathrm{W}$, a climate classified as mesothermal humid subtropical (Cfa), with a dystrophic Red Latosol.

The techniques and materials used followed the norms established by the certification of the experimental area. The tomato variety used was the Cordillera (F1 hybrid), which produces Italian-type tomatoes, with a higher value-added in the marketplace, and which is tolerant to spotted wilt virus (TSWV5), yellow leaf curl virus (TYLCV), Fusarium oxysporum strain no. 2, Verticilliumalbo-atrum, and 
Economic viability of organic farming system

Verticillium dahliae. The spacing between rows was $1.2 \mathrm{~m}$, with $0.7 \mathrm{~m}$ between plants $(11,905$ plants per hectare), one stem per plant and with coriander (Coriandrumsativum)intercalated in the planting row $^{2}$. Fertilization was organic, with the application of 18 tons of fertilizer per hectare, applied and incorporated to a depth and width of $30 \mathrm{~cm}$. Seven additional tons per hectare were applied together with the hilling, 25 days after the tomato seedlings were transplanted. As for the remaining crop treatment, periodic manual weeding was carried out to control spontaneous plant development. Forage grasses grew between the crop rows with a layer approximately $5 \mathrm{~cm}$ high. Nipping and staking were performed weekly to obtain fruit that met commercial standards. Each raceme was bearing, leaving eight fruits in the first two racemes and six fruits on the remainder.

At the start of the harvesting period, two applications of Bacillus thuringiensis were undertaken (at a ratio of $80 \mathrm{~g}$ of product for every 100 liters of water), at two-weekly intervals, in order to prevent attack by the corn earworm (Helicoverpazea), South American tomato moth (Tuta absoluta), and the small fruit fly (Neoleucinodes elegantalis). To manage these diseases, seven sprayings were carried out over the course of the crop cycle, using citral $\left(400 \mu \mathrm{L} . \mathrm{L}^{-1}\right)$, a component extracted from essential oil of lemongrass (Cymbopogon citratus).

The production was evaluated from the first harvest, in the first raceme; 81 days after the seedlings were planted, and ended with the $7^{\text {th }}$ raceme, at 146 days. On average, two harvests were conducted every week.

\section{Conventional farming system}

Cultivation was carried out on the property of a farmer who produces tomatoes in the metropolitan region of Maringá, in the state of Paraná, following the techniques and practices that the farmer normally uses. The property has the following characteristics: altitude of $473 \mathrm{~m}$, latitude $23^{\circ} 32^{\prime} \mathrm{S}$, longitude $51^{\circ} 50^{\prime} \mathrm{W}$, mesothermal humid subtropical climate (Cfa), with dystrophic Red Latosol.

The tomato variety used was the same as that adopted by the organic farming system (Cordillera), and the crop was planted in the same week. Techniques adopted by the conventional farmer included the avoidance of herbicide use prior to planting, tilling of the soil using a rotavator, and the application of weeding during the crop cycle. . To fertilize the plantation, 1.8 tons per hectare of organic fertilizer and 3.5 tons per hectare of chemical fertilizer (N-P-K/4-30-10) were used, both applied to the plantation furrow. Plants were spaced $1 \mathrm{~m}$ apart, with $0.5 \mathrm{~m}$ between rows and one stem per plant, totaling 20,000 plants per hectare, i.e. 8,095 plants per hectare more than in the organic farming system. Two fertilizations were carried out using ammonium sulfate, with approximately $10 \mathrm{~g}$ per plant at each fertilizing. The first fertilization occurred at the start of the crop cycle, together with the hilling, and the second fertilization occurred at the beginning of the harvest. The application of foliar fertilizer (calcium + boron) was carried out periodically, mainly after the beginning of the reproductive phase, and nipping and staking were performed weekly. Each raceme was bearing, leaving eight fruits per raceme.

Related to plant management, on average two sprayings were carried out every week with product rotation. To control insects, Cartape, Rynaxypyr ${ }^{\circledR}$, Imidacloprido and Dipel were used, the latter being used after the initiation of harvesting. For disease control, Copper Oxychloride, Mancozeb, and Azoxystrobin were used. During the harvest, in order to respect the withholding periods, products with less grace-period ${ }^{2}$ Using coriander as a companion plant reduces the population of the Silver leaf whitefly (Bemisia tabaci), and could
be a viable alternative for preventing the occurrence of tomato plant viruses $\left[{ }^{10}\right]$. 
were used. To obtain the cost of insecticides and fungicides, an average price per kilo of active ingredient was established, observing the proportions used for each product.

The first harvesting, in the first raceme, was carried out 75 days after the seedlings were planted and continued up until the $8^{\text {th }}$ raceme, at 158 days. On average, two harvests were carried out each week.

\section{Economic analysis}

In order to calculate the cost of production in both cultivation systems, a production area of $1,000 \mathrm{~m}^{2}$ was used. For the calculation of economic viability, all services and inputs were considered, as well as productivity observed in both cultivation systems and the price of the organic and conventional tomatoes in the local market.

Return on equity (ROE) in respect of the land (area of $1,000 \mathrm{~m}^{2}$ )for tomato production was calculated considering the average price per hectare (US\$10,232.56) and the investment of this amount in a savings account at $7.5 \%$ p.a..

As far as fixed costs are concerned (depreciation(DEP), maintenance and $\mathrm{ROE}^{3}$ ), related to the installation of the support system, the peculiarities of each system were taken into account (Tables1 and 2). The reduced spacing in conventional cultivation resulted in a larger number of linear meters of cultivation rows and, consequently, greater use of posts, flat wire, and tensioners, among other costs. On the other hand, with organic crops there is a requirement for certification which, in the present case, is shared, thereby significantly reducing the cost of this item. For DEP, the cost required to replace assets when they become unusable is accounted for, and ROE or opportunity cost may be considered as the revenue which would have been obtained if the farmer had invested his capital in another activity. In this case, we considered the investment in a savings account, with interest at $7.5 \%$ p.a. Thus the DEP and ROE were based on the following equations:

$$
\begin{gathered}
\mathrm{DEP}=\frac{\mathrm{TP}-\mathrm{PS}}{\mathrm{UL}} \\
\mathrm{ROE}=\left(\frac{\mathrm{TP}+\mathrm{PS})}{2}\right) \cdot 0.075
\end{gathered}
$$

where TP is the current total price of the item; PS is the price of scrap (i.e. the price of the item after being sensibly used in the activity), and UL is the useful life.

The support system is only used for six months in tomato cultivation, while it is possible for it to be used in the remainder of the year by other crops which also require staking. Accordingly, assuming that tomato growing is the main activity in the area, it will be responsible for bearing $60 \%$ of the fixed and variable costs in respect of the conveyance structure in both the organic and conventional systems. In both systems, irrigation was performed using a drip tape with drip lines $30 \mathrm{~cm}$ apart, and with an individual maximum rate of flow of 2 liters per hour, such that the frequency of irrigation, as well as duration, depended on the age of the crop, soil humidity, and meteorological conditions. For the irrigation, a $0.5 \mathrm{hp}$ pump was employed, at a cost of US $\$ 60.71$, a voltage of $220 \mathrm{v}$, output of $0.37 \mathrm{~kW} \cdot \mathrm{h}^{-1}$ and average operating time of 90 minutes per day for 150 days, the electricity cost being US\$ 7.95ofthe total cost.

The losses corresponding to fruits graded with serious defects (grading based on

\footnotetext{
${ }^{3}$ The present study differs from others that analyze economic viability in farming activity without taking into account (either partially or totally) depreciation and return on equity, and therefore overestimate profits from the activity $[11,12,13]$.
} 
Economic viability of organic farming system

MAPA $^{4}$ SARC $^{5}$ directive no. 85 of March 6, 2002) were considered. Net revenue from organic cultivation and the earnings obtained by selling the coriander, the tomato's companion plant, were summed, such that the expenses incurred with this companion plant arrangement were included in the calculations of the organic tomato plant. The coriander was harvested on three occasions: the first took place three days before the planting of the tomatoes, the second and third at intervals of 3 and 4 weeks, respectively.

Revenues were calculated using the total fruit yield $\left(\mathrm{kg}\right.$ per $\left.1000 \mathrm{~m}^{2}\right)$ obtained in each system. The trade price used, both for the conventional and the organic product, corresponds to the one used in direct trade (street markets) in Maringá during the period in which the study was conducted. The subdivision in the trade price stipulated for the organic tomato is due to the fact that fruits without defects have a higher value-added and, therefore, are sold at a higher price than tomatoes with a slight defect grading, which are usually diverted into the production of sauce or dried tomatoes.

Prices paid correspond to April 2011 and the prices received to October 2011. All monetary values were deflated by the Ample Consumer Price of the National Index from the Brazilian Institute of Geography and Statistics for December 2015, and were later converted into US dollars using the average exchange rate from December 2015.

\section{RESULTS AND DISCUSSION}

The results of maintenance costs related to the support system for tomato plants in the organic farming and conventional systems are presented in Table 1. Note that the support-system maintenance cost in the conventional system is higher due to the larger number of plants in the same area.

Table 1. Maintenance of the support system for tomato plants cultivated in organic farming and conventional system (in US dollars - US\$)*

\begin{tabular}{|c|c|c|c|c|c|}
\hline \multirow{2}{*}{ Item } & \multirow{2}{*}{$\mathbf{M A}^{* *}$} & \multicolumn{2}{|l|}{ Organic } & \multicolumn{2}{|c|}{ Conventional } \\
\hline & & PN & MC & $\mathbf{P N}$ & MC \\
\hline Posts & 1 & $1,560.03$ & 15.6 & $1,950.04$ & 19.5 \\
\hline Concrete rail & 1 & 178.34 & 1.78 & 222.94 & 2.23 \\
\hline Flat wire $-16 "$ & 1 & 153.38 & 1.53 & 184.37 & 1.84 \\
\hline Tensioners & 2 & 38.58 & 0.77 & 48.22 & 0.96 \\
\hline Drip Tape & 5 & 73.75 & 3.69 & 88.64 & 4.43 \\
\hline Irrigation pipes $-2 "$ & 2 & 72.22 & 1.44 & 72.22 & 1.44 \\
\hline Pump - 0.5hp & 2 & 63.11 & 1.26 & 63.11 & 1.26 \\
\hline Automatic valve & 5 & 112.04 & 5.6 & 112.04 & 5.6 \\
\hline 10,000 liter water reservoir & 0 & 744.56 & 0 & 744.56 & 0 \\
\hline Hoe & 2 & 27.66 & 0.55 & 27.66 & 0.55 \\
\hline Backpack sprayer - 20 liters & 3 & 46.09 & 1.38 & 46.09 & 1.38 \\
\hline Total & & & 33.60 & & 39.19 \\
\hline Total $(60 \%)$ & & & 20.16 & & 23.51 \\
\hline
\end{tabular}

The cost of depreciation and return on equity of the tomato support system relating to investments for the cultivation of tomato and land prices can be seen in Table 2,

\footnotetext{
${ }^{4}$ MAPA - Brazilian Ministry of Agriculture, Livestock, and Food Supply.

${ }^{5}$ SARC - Department of Rural Support and Farm Cooperatives
} 
which shows a higher cost for the conventional production system. It should be noted that in both farming systems, depreciation and return on equity was adjusted to $60 \%$ of its total annual value in consideration of the fact that the tomato crop, even though the main activity, occupies the land for a little over six months.

Table 2. Depreciation and return on equity of the tomato support system, cultivated in organic farming system and conventional system (in US dollars - US\$) ${ }^{*}$.

\begin{tabular}{|c|c|c|c|c|c|c|c|c|c|}
\hline Item & Qty & $\mathbf{U P}$ & TP & $\mathbf{U L}$ & $\mathbf{R P}$ & PS & DEP & ROE & Total \\
\hline & \multicolumn{9}{|c|}{ Organic } \\
\hline Installation of support system & 5.66 man days & 14.18 & 80.26 & 10 & - & - & 8.03 & 3.01 & 11.04 \\
\hline Posts** & 80 units & 19.50 & $1,560.0$ & 10 & - & - & 156.00 & 58.50 & 214.50 \\
\hline Concrete rail & 32 units & 5.57 & 178.24 & 30 & - & - & 5.94 & 6.68 & 12.62 \\
\hline Flat wire - 16" & $1664 \mathrm{~m}$ & 0.09 & 149.76 & 20 & 15 & 22.5 & 6.52 & 6.62 & 13.14 \\
\hline Tensioner & 32 units & 1.21 & 38.72 & 15 & 15 & 5.8 & 2.19 & 1.66 & 3.85 \\
\hline Drip tape & $832 \mathrm{~m}$ & 0.09 & 74.88 & 6 & - & - & 12.48 & 2.81 & 15.29 \\
\hline Certification & 0.1 ha & 34.04 & 3.40 & - & - & - & 0.00 & 0.13 & 0.13 \\
\hline \multirow[t]{2}{*}{ Sub-total } & & & & & & & 191.16 & 79.41 & 270.57 \\
\hline & \multicolumn{9}{|c|}{ Conventional } \\
\hline Installation of support system & 6.78 man days & 14.18 & 96.14 & 10 & - & - & 9.61 & 3.61 & 13.22 \\
\hline Posts ${ }^{* *}$ & 100 units & 19.50 & $1,950.0$ & 10 & - & - & 195.00 & 73.13 & 268.13 \\
\hline Concrete rail & 40 units & 5.57 & 222.80 & 30 & - & - & 7.43 & 8.36 & 15.79 \\
\hline Flat wire - 16" & $2000 \mathrm{~m}$ & 0.09 & 180.00 & 20 & 15 & 78.00 & 7.84 & 7.95 & 15.79 \\
\hline Tensioner & 40 units & 1.21 & 48.40 & 15 & 15 & 20.40 & 2.73 & 2.08 & 4.81 \\
\hline Drip tape & $1000 \mathrm{~m}$ & 0.09 & 90.00 & 6 & - & - & 15.00 & 3.38 & 18.38 \\
\hline \multirow[t]{2}{*}{ Sub-total } & & & & & & & 237.61 & 98.51 & 336.12 \\
\hline & \multicolumn{9}{|c|}{ In Common } \\
\hline Irrigation pipes - 2" & $70 \mathrm{~m}$ & 1.03 & 72.10 & 15 & - & - & 4.81 & 2.70 & 7.51 \\
\hline Pump $-0.5 \mathrm{hp}$ & 1 unit & 63.11 & 63.11 & 12 & 20 & 35.60 & 4.21 & 2.84 & 7.05 \\
\hline Automatic valve & 1 unit & 112.04 & 112.04 & 10 & - & - & 11.20 & 4.20 & 15.40 \\
\hline 10,0001 water reservoir & 1 unit & 744.56 & 744.56 & 20 & - & - & 37.23 & 27.92 & 65.15 \\
\hline Hoe & 3 units & 9.22 & 27.66 & 7 & 10 & 7.80 & 3.56 & 1.14 & 4.70 \\
\hline Backpack Sprayer - 201 & 1 unit & 46.09 & 46.09 & 7 & 10 & 13.00 & 5.93 & 1.90 & 7.83 \\
\hline Return on land & 0.1 ha & $10,636.6$ & $1,063.7$ & - & - & - & - & 39.89 & 39.89 \\
\hline Sub-total & & & & & & & 66.94 & 80.59 & 147.53 \\
\hline Total - Organic & & & & & & & & & 418.10 \\
\hline Total - Organic $(60 \%)$ & & & & & & & & & 250.86 \\
\hline Total - Conventional & & & & & & & & & 483.65 \\
\hline Total - Conventional $(60 \%)$ & & & & & & & & & 290.19 \\
\hline
\end{tabular}

Fixed costs (maintenance, DEP and ROE) related to the support system came to US\$271.02 a year in the organic farming system and US\$ 313.7 a year in the conventional system (Tables 1 and 2). These values account for $13.17 \%$ and $11.13 \%$ of the total production costs for the organic and conventional systems, respectively. Table 3 shows the total cost for both production systems. Given an area of 0.1 ha, with similar climate and soil conditions, the total cost of production in the conventional system (US\$2,817.33) was higher than in the organic system (US\$2,058.45). However, the cost per plant was higher in the organic system (US\$ 1.73) than in the conventional system (US\$ 1.41). It should be pointed out that this result considered the larger population of plants encompassed in the conventional system, which utilized 8,095 more plants than did the organic system. That is, the conventional system supported $68 \%$ more plants in an equivalent area. 
Economic viability of organic farming system

Table 3. Cost of production of the tomato plant crop in an organic farming system compared with the conventional system (in US dollars - US\$)*.

\begin{tabular}{|c|c|c|c|c|c|c|c|}
\hline \multirow{2}{*}{ Item } & \multirow{2}{*}{ Unit } & \multicolumn{3}{|c|}{ Organic $^{1}$} & \multicolumn{3}{|c|}{ Conventional $^{2}$} \\
\hline & & Qty & $\mathbf{U P}$ & TC & Qty & $\mathbf{U P}$ & TC \\
\hline \multicolumn{8}{|l|}{ Services performed } \\
\hline & machine & & & & & & \\
\hline Field preparation & hours & 2 & 31.91 & 63.82 & 2 & 31.91 & 63.82 \\
\hline Fertilization & man hours & 40.87 & 1.77 & 72.34 & 40.87 & 1.77 & 72.34 \\
\hline Production of tomato seedlings & man hours & 20.92 & 1.77 & 37.03 & 35.15 & 1.77 & 62.22 \\
\hline Production of coriander seedlings & man hours & 16.43 & 1.77 & 29.08 & - & - & - \\
\hline Preparation of the support system & man hours & 32.92 & 1.77 & 58.27 & 32.92 & 1.77 & 58.27 \\
\hline Preparation of irrigation & man hours & 16.46 & 1.77 & 29.13 & 16.46 & 1.77 & 29.13 \\
\hline Planting tomatoes & man hours & 21.43 & 1.77 & 37.93 & 36.01 & 1.77 & 63.74 \\
\hline Planting coriander & man hours & 21.43 & 1.77 & 37.93 & - & - & - \\
\hline Weeding & man hours & 82.3 & 1.77 & 145.67 & 82.3 & 1.77 & 145.67 \\
\hline Fertilizing top-dressing and ridging & man hours & 38.41 & 1.77 & 67.99 & 48.41 & 1.77 & 85.69 \\
\hline Nipping and staking & man days & 15.72 & 14.18 & 222.91 & 26.42 & 14.18 & 374.64 \\
\hline Spraying & man hours & 21.34 & 1.77 & 37.77 & 150.7 & 1.77 & 266.74 \\
\hline Harvesting and grading - tomato & man days & 10.74 & 14.18 & 152.29 & 16.38 & 14.18 & 232.27 \\
\hline Harvesting and grading - coriander & man hours & 27.35 & 1.77 & 48.41 & - & - & - \\
\hline Technical support ${ }^{3}$ & vis. & 5 & 14.18 & 70.9 & 5 & 14.18 & 70.9 \\
\hline Sub-total & & & & $1,111.47$ & & & $1,525.43$ \\
\hline \multicolumn{8}{|l|}{ Inputs } \\
\hline Tomato seeds & unit & $1,190.0$ & 0.09 & 107.1 & $2,000.0$ & 0.09 & 180 \\
\hline Coriander seeds & $\mathrm{g}$ & 23.7 & 0.04 & 0.95 & - & - & - \\
\hline 162-cell plastic trays & unit & 9 & 4.79 & 43.11 & 13.83 & 4.79 & 66.25 \\
\hline Substrate & $\mathrm{kg}$ & 27.43 & 0.25 & 6.86 & 46.11 & 0.25 & 11.53 \\
\hline PPE Kit & unit & 1 & 15.95 & 15.95 & 3 & 15.95 & 47.85 \\
\hline Seal of certification & unit & $8,000.0$ & 0.01 & 80 & - & - & - \\
\hline Organic fertilizer ${ }^{4}$ & $\mathrm{~kg}$ & $2,519.0$ & 0.12 & 302.28 & 493.8 & 0.07 & 34.57 \\
\hline NPK chemical fertilizer $(4-30-10)$ & $\mathrm{kg}$ & - & - & - & 350 & 0.5 & 175 \\
\hline Ammonium sulfate & $\mathrm{kg}$ & - & - & - & 100 & 0.35 & 35 \\
\hline Lime & $\mathrm{kg}$ & 50 & 0.06 & 3 & 50 & 0.06 & 3 \\
\hline Electricity & $\mathrm{kWh}$ & 83.25 & 0.1 & 8.33 & 83.25 & 0.1 & 8.33 \\
\hline Fungicides & $\mathrm{kg} \mathrm{AI}$ & - & - & - & 5.04 & 21.45 & 108.11 \\
\hline Insecticides & $\mathrm{kg} \mathrm{AI}$ & - & - & - & 3.57 & 74.46 & 265.82 \\
\hline Foliar fertilizer $(\mathrm{Ca}+\mathrm{B})$ & $\mathrm{L}$ & - & - & - & 7.61 & 1.99 & 15.14 \\
\hline Citral $\left(400 \mu \mathrm{L} \mathrm{L}^{-1}\right)$ & $\mathrm{mL}$ & 360.72 & 0.29 & 104.61 & - & - & - \\
\hline Bacillus thuringiensis & $\mathrm{kg}$ & 0.33 & 18.01 & 5.94 & 1.66 & 18.01 & 29.9 \\
\hline Sub-total & & & & 678.13 & & & 980.50 \\
\hline Total (Services Performed and Inputs) & & & & $1,789.60$ & & & $2,505.93$ \\
\hline Maintenance & & & & 20.16 & & & 23.51 \\
\hline Depreciation + ROE & & & & 248.69 & & & 287.89 \\
\hline Total cost & & & & $2,058.45$ & & & $2,817.33$ \\
\hline Cost per plant & & & & 1.73 & & & 1.41 \\
\hline
\end{tabular}

The conventional system assigns higher priority to productivity, as is the case with the production of the high-density tomato, with 44,000 plants per hectare and commercial production of up to 152 tons per hectare $\left[{ }^{15}\right]$. However, if on the one hand the overcrowding of plants seeks to maximize the use of space and manpower 
and reduce the cost per plant, on the other hand it increases the probability and dispersal of disease which, in all likelihood, would require a greater number of sprayings and intensive injection of rapid-effect chemical fertilizers.

In regard to effective operating costs, the cost of labor-related services represented $53 \%$ in both systems, demonstrating that both models possess proportional manpower usage (Table3). The higher expense on this item in the conventional system can be attributed to the greater number of sprayings and the higher number of plants, resulting from the reduced spacing. Similar results were found in other studies: approximately $40 \%$ of the cost of production was related to manpower, using a production system that is largely unmechanized $\left[{ }^{16}\right]$.

The costs of extensive crops, such as corn and soybean, in the organic farming system could involve up to $35 \%$ higher labor costs when compared to the conventional system $\left[{ }^{17}\right]$. However, as growing tomatoes is highly exacting in terms of crop treatment, there will be a high demand for labor no matter which farming system is employed, causing the difference in costs for this item to be negligible between systems. These results are linked to the large number of manual operations that occur during tomato cultivation, with labor being one of the items with the largest impact on production costs.

When comparing just the cost of plant management, the organic alternative, citral $400 \mu \mathrm{L} . \mathrm{L}^{-1}$ was 2.33 times lower than the conventional system, to the extent that it represented only $6 \%$ of the total cost of production in the organic system, while chemical control in the conventional system accounted for $14 \%$. Another item that revealed noteworthy differences between the systems was fertilization. In the organic system, this accounted for $15 \%$ (certified organic fertilizer) and, in the conventional system, $9 \%$ of the total cost of production. Items like services, fixed costs, seeds, and other inputs showed similar production cost.

Plant management in organic cultivation was less expensive than the management adopted in the conventional system. The volume of spray-mix used in the conventional system was higher than in the organic system, as the former performed two sprayings a week while the latter carried out just seven sprayings over the course of the entire crop cycle.

Nevertheless, taking into account the intrinsic characteristics of each system and the resulting costs (Table 3), and the fact that in the conventional crop system more than seven sprayings were required over the course of the crop cycle, it is possible to attribute to the organic system a lower cost in terms of plant management.

Table 4shows commercial productivity of fruits without defects, with slight defects, the price paid in direct trading (street market),and total net revenue, including the revenue obtained through the sale of the coriander that was cultivated as a companion plant to tomatoes in the organic farming system. Note that cultivation in a system of organic farming generated higher net revenue than in the conventional system. This is due to the lower total cost of production and the higher added value of the product. 
Economic viability of organic farming system

Table 4. Net revenues obtained from the tomato plant crop in an organic farming system and in a conventional system (in US dollars - US\$)*.

\begin{tabular}{|c|c|c|c|c|c|c|c|c|c|c|}
\hline \multirow{2}{*}{ System } & \multicolumn{3}{|c|}{ Production $\left(\mathrm{kg} / \mathbf{1}, 000 \mathrm{~m}^{2}\right)$} & \multicolumn{4}{|c|}{ Net revenues $\left(\mathrm{US} \$ \mathbf{1 , 0 0 0 m ^ { 2 } )}\right.$} & \multirow{2}{*}{ Total cost } & \multirow{2}{*}{$\begin{array}{l}\text { Cost } \\
\text { per Kg }\end{array}$} & \multirow{2}{*}{$\begin{array}{l}\text { Net } \\
\text { revenue }\end{array}$} \\
\hline & $\mathbf{N D}^{* *}$ & $\mathbf{S D}^{* * *}$ & Total & $\mathbf{N D}^{* *}$ & $\mathbf{S D}^{* * *}$ & Coriander & Total & & & \\
\hline Organic & $3,894.5$ & 707.7 & $5,515.3$ & $6,737.49$ & 608.62 & 608.26 & $7,954.37$ & $2,058.45$ & 0.37 & $5,895.92$ \\
\hline
\end{tabular}

*Values at December 2015. ** Price paid per kg of tomatoes without defects: organic US\$ 1.73 and conventional US\$ 0.86. *** Price paid per $\mathrm{kg}$ of organic tomatoes with slight defects: US\$ 0.86. ND - tomato without defects; SD - tomato with slight defects.

In organic tomato cultivation, it is possible to achieve $80 \%$ of the total productivity in terms of volume $(\mathrm{kg})$ obtained in the conventional system and, over time, with increased soil fertility and improvements in management, the organic system could obtain a significant improvement in production $\left[^{1}\right]$. The difference in productivity between the two cultivation systems is minimized when it is considered that, in the organic system, there is a lower inflow of external inputs and the selling price of the final products is higher.

The lower plant population and lower productivity in the organic farming system, resulted in a production cost per $\mathrm{kg}$ of tomatoes higher than in the conventional system (Table 4). The cost of producing one $\mathrm{kg}$ of organic tomatoes was $23.3 \%$ higher than the cost of producing one $\mathrm{kg}$ of conventional tomatoes.

According to the Rural Economy Department of Paraná State, the average tomato productivity in the region of Maringa in 2011 was $43.4 \mathrm{t} \mathrm{ha}^{-1}\left[{ }^{18}\right]$. Thus, even with a lower productivity than that obtained in the conventional system, the organic farming system achieved a productivity above the regional average, which demonstrates the good productive potential of the system.

Tomato growing via organic systems is profitable even when compared with other herbaceous plants that demonstrate good productivity and added value, as is the case with the organic sweet potato $\left[{ }^{19}\right]$ and lettuce $\left[{ }^{20}\right]$. Organic products, as they purport to be a healthier food for the consumer, are assured a price premium when traded, $\left[{ }^{3}\right]$ which could equate to a level of profitability as much as $113.6 \%$ higher than with conventional products $\left[{ }^{21}\right]$.

\section{CONCLUSIONS}

In the conventional system, the cost of plant management was 2.33 times higher, considering that the number of sprayings was higher than that carried out in organic cultivation.

Using companion plants, such as coriander, in addition to helping with the management of the main crop, is important for economic sustainability as it generates an additional source of revenue.

Considering the specificities of the two systems, organic cultivation, despite producing lower yields, could exceed the profitability of the conventional cultivation system. 


\section{REFERENCES}

1. SeufertV,Ramankutty N, Foley JA. Comparing the yields of organic and conventional agriculture. Nature. 2012, 485: 229-232.

2. PatilS, Reidsma P, Shah P, Purushothaman S, Wolf J. Comparing conventional and organic agriculture in Karnataka, India: Where and when can organic farming be sustainable? Land Use Policy. 2014, 37: 40-51.

3. Crowder DW, Reganold JP. Financial competitivenessof organic agriculture on a global scale. ProcNatlAcadSci USA. 2015, 112: 7611-7616.

4. Mazzoleni EM, Nogueira JM. Agricultura orgânica: características básicas do seu produtor. Rev. Econ. Sociol. Rural. 2006, 44: 263-293.

5. Campanhola C., Valarini PJ. Organic agriculture and its potential for small holders.Cad. Ciên. Tecnol. 2001, 18: 69-101.

6. Fuck MP, Bonacelli MB. The public research agenda and the possibilities for agriculturaldevelopment. Estud. Soc. Agric. 2008, 16: 5-26.

7. Ponti T, Rijk B, van Ittersum MK. The crop yield gap between organic and conventional agriculture. Agr Syst. 2012, 108: 1-9.

8. Ponisio LC, M'Gonigle LK, Mace KC, Palomino J, de Valpine P, Kremen C. Diversification practices reduce organic to conventional yield gap. Proc $R$ Soc B.2015, 282:20141396.

9. Wezel A, Casagrande M, Celette F, Vian JF, Ferrer A, Peigné J. Agroecological practices for sustainable agriculture. A review. Agron Sustain Dev. 2014, 34: 1-20.

10. Togni PHB, Frizzas MR, Medeiros MA, Nakasu EYT, Pires CSS, Sujii ER. Population dynamic of Benisuatabaci B biotype in monoculture tomato crop and consortium with coriander in organic and conventional crop system. Hortic Bras. 2009, 27: 183-188.

11. Miguel FB, Esperancini MST, Simon EJ, Bárbaro IM, TicelliM.Profitability analysis of organic lettuce and carrot cropping production in Bebedouro, Sao Paulo State, Brazil, 2006. Inf Econ. 2008, 38: 51-58.

12. Zárate NAH, Vieira MC, Sousa TM, Ramos DD. Yield and net income of unripe corn in function of the hilling dates. SeminCiencAgrar. 2009, 30: 95-100, 2009.

13. Assi L, Stangarlin JR, PortzRL.Disease control in strawberry plants in differentcropping systems: a study on sustainability.SciAgrar Parana.2010, 9: 58-67, 2010.

14. CONAB - Companhia Nacional de Abastecimento. Custos de produção agrícola: a metodologia da Conab. Brasília, 2010. 60 p.

15. Wamser AF, Mueller S, Becker WF, Santos JP, Suzuki A. Evaluation of tomato production in superdensity system, in Caçador, Brazil. Hortic Bras. 2008, 26: 5064-5070.

16. Franzener G, Balbi-Peña MI, Assi L, Stangarlin JR, Portz RL. Controle da pinta preta do tomateiro pelo extrato de cúrcuma: um estudo de caso sobre a sustentabilidade. SciAgrar Parana.2009, 8: 99-112.

17. Pimentel D,Hepperly P, Hanson J,Douds D, Seidel R. Environmental, energetic, and economic comparisons of organic and conventional farming systems. BioScience. 2005, 55: 573-582.

18. Departamento de Economia Rural, Secretaria da Agricultura e do Abastecimento do Estado do Paraná.Produção agropecuária. Disponível em: 〈www.agricultura.pr.gov.br〉. Accessed on: October 7, 2016.

19. Melo AS, Costa BC, Brito MEB, Aguiar Netto AO, Viégas PRA. Cost and profitability of sweet potato production in the irrigated perimeter of Itabaiana, Sergipe, Brazil. PesquiAgropecu Trop. 2009,39: 119-123.

20. AraújoNeto SE, Ferreira RLF, Pontes FST.Profitability of lettuce cultivars organic production in greenhouse and field with different tillage soil. Cienc Rural. 2009, 39: 1362-1368.

21. Luz JMQ, Shinzato AV, Silva MAD. Comparison of conventional and organic tomato growing underprotected cultivation. Biosci J.2007, 23: 7-15. 
Economic viability of organic farming system

\section{Erratum}

In Article "Economic Viability of Tomato Cultivation in Organic Farming System", with DOI number: http://dx.doi.org/10.1590/1678-4324-2017161229, published in journal Brazilian Archives of Biology and Technology, vol. 60, the 01 page.

That read:

"http://dx.doi.org/10.190/1678-4324-2017161229"

Read:

“http://dx.doi.org/10.1590/1678-4324-2017161229" 